\title{
McDowell e as estátuas de Dédalo
}

\author{
João Carlos Brum Torres \\ Fundacao Universidade de Caxias do Sul \\ Rua Francisco Getúlio Vargas, 1130 Caxias do Sul \\ RS 95070-560 \\ Brazil \\ brumtorres@gmail.com
}

\author{
Article info \\ CDD: 121 \\ Received: 13.06.2016; Revised: 11.10.2016; Accepted: 22.10.2016 \\ DOI: http://dx.doi.org/10.1590/0100-6045.2016.V39N3.JT
}

\author{
Palabras clave/ Keywords: \\ Conceito demonstrativo \\ Memória \\ Posse de conceitos \\ Formação de conceitos
}

\begin{abstract}
The subject of this paper is the concept of 'demonstrative concept', which has been introduced in philosophy by John McDowell in Mind and World. The analysis presented in the article has a reconstructive and a critical character. Its reconstructive drive may be viewed as required by the concise mode the philosopher adopted to present his theoretical innovation and comprehends an effort to make clear: (i) what is the difference between the temporal conditions necessary (a) to give conceptual status to the color shade we have before our eyes and (b) to our possession of ordinary concepts; (ii) the sui generis character of the universality proper to demonstrative concepts and the uniformity of their relations to what they are concepts of; (iii) the equivalence of their semantical regime to that which is proper to concepts of measurement standards; (iv) the very singular function performed by memory in the constitution and possession of demonstrative concepts. Now, the critical character of the paper firstly lies in the remark that there is a kind of inconsequence in the way McDowell conceives the employment of those concepts, namely in his refusal to admit that even though it is natural to say 'I see the shade in my mind's eye', it would be a mistake to think that when we recognize a color shade as being the same as the one we have seen before there is an inner comparison of it with the retained sample. The second of the paper critical points is the warning that, considering the complex constitution process of demonstrative concepts and its exacting semantic, it seems impossible to take them as coextensive to our human experience of colors.
\end{abstract}




\section{Preliminares}

Ao discutir a passagem de Varieties of Reference em que Evans pergunta se "entendemos realmente a sugestão de que possuímos tantos conceitos de cor quantas são as tonalidades que somos capazes de discriminar sensorialmente" (1992, p. 229). McDowell redargui perguntando por sua vez:

Mas por que deveríamos aceitar que a habilidade de abarcar cores no pensamento conceitual restrinja-se a conceitos passíveis de serem expressos em palavras como 'vermelho', 'verde', ou 'castanho queimado'? (1996, p. 56/2005, p. 94)

A alternativa que lhe parece natural é pensar que:

Em meio a uma experiência do tipo que supostamente transcende nossas capacidades conceituais - experiência que ex hypothesi fornece uma amostra adequada - podemos dar expressão lingüística a um conceito que tem exatamente a mesma granulação da experiência pronunciando uma frase como 'aquele matiz', na qual o demonstrativo se vale da presença da amostra. (1996, p. 56/2005, p. 94)

Muito embora esta não seja propriamente a certidão de nascimento do conceito de "conceito demonstrativo", parece ser na passagem que acaba de ser citada que demonstrativos complexos, como "esta tonalidade" ou "este formato", foram formalmente apresentados com o objetivo de sustentar a tese de que o universo conceitual é integralmente coextensivo ao

${ }^{1}$ A expressão aparece, por exemplo, já na primeira página do primeiro capítulo de A Study of Concepts de Peacocke (1992), cuja publicação antecede em dois anos a de Mind and World. Sobre o uso da expressão conceito demonstrativo cf. (Kelly, 2001, p. 401, nota 7). Ao que consta, o uso da expressão foi antecipado por meios mais informais de apresentação e divulgação de ideias, como se depreende da declaração de Peacocke de que "A defesa do emprego de conceitos demonstrativos em posição predicativa, assim como enquanto singulares foi feita por McDowell (a ser publicado) e por Sedivy (1991)." (1992, p. 83).

Manuscrito - Rev. Int. Fil. Campinas, v. 39, n. 3, pp. 199 - 235, jul.-set. 2016. 
universo da experiência. ${ }^{2}$ Meu objetivo no presente texto não será, contudo, discutir diretamente essa tese nem o sucesso ou insucesso que McDowell tenha tido em sua defesa, mas antes examinar sua proposta de introdução do conceito de "conceito demonstrativo" na teoria dos conceitos. $\mathrm{Na}$ verdade, tratando de apresentá-la em alguma medida reconstrutivamente, tendo em vista, por um lado, a brevidade com que McDowell introduz sua inovação, e, por outro, o que me parece ser uma incoerência de seu desenvolvimento. Assim, a primeira seção do texto fará uma exposição preliminar dos traços destacados por McDowell como próprios desses conceitos. A segunda será dedicada à apresentação das propriedades semânticas dos conceitos ordinários e do tipo de condicionamento temporal a que está submetida sua posse, de modo a obter um plano de contraste para mais fácil e mais segura avaliação do caráter distintivo dos conceitos demonstrativos. A terceira seção cuidará de examinar com maior detalhe a especificidade semântica de tais conceitos e a particular temporalidade que lhes é própria, a qual tem como traço distintivo, como se verá, uma forma de dependência da posse conceitual da memória que é completamente diferente da que se vê no caso de conceitos sortais ou caracterizadores. A quarta seção tratará de objeções que podem ser feitas à intepretação do conceito de conceito demonstrativo apresentada neste artigo, inclusive uma objeção textual que, conquanto inequivocamente sustentada por uma passagem de Mind and $W$ orld, me parece decorrer de uma inconsequência de análise. Por fim, em uma anotação conclusiva, se procurará mostrar que as particularidades dos conceitos demonstrativos fazem com que tanto sua forma lógica, quanto o regime semântico que lhes são próprios tenham que ser reconhecidos como equivalentes aos dos conceitos que constituem padrões de medida.

\footnotetext{
2 Muito embora o conceito de conceito demonstrativo faça pensar imediatamente na panaceia universal - eis que promete viabilizar a conversão instantânea e sem restrições de qualquer conteúdo perceptivo em conteúdo conceitual! -, McDowell ao apresentá-lo acautelou-se e advertiu: "Precisamos tomar cuidado com o tipo de capacidade conceitual envolvida aqui." (1996, p. 56/2005, p. 94).
}

Manuscrito - Rev. Int. Fil. Campinas, v. 39, n. 3, pp. 199 - 235, jul.-set. 2016. 


\section{A caracterização geral do conceito de conceito demonstrativo}

A ideia principal de McDowell com relação a este assunto e a justificativa para introdução do conceito de conceito demonstrativo são simples: não importa quão variada seja nossa experiência, se ela for uma experiência humana será conceitual e nossa falta de termos gerais para classificação ou categorização da variedade ilimitada dos aspectos singularizados do que nos é oferecido pela experiência não diminui um átimo da potência inesgotável que temos para apreender conceitualmente o mundo. Para dar-se conta disso, diz Brewer, secundando muito utilmente a McDowell, basta que abandonemos o pressuposto de que conceitos "necessariamente correspondem a classificações das coisas (....) inteiramente independentes do contexto" (1999, p. 171) e que, ao invés, passemos a reconhecer que demonstrativos complexos $^{3}$, justamente por estarem intrinsecamente vinculados a seus contextos de uso, viabilizam o fornecimento ilimitado de todos os conceitos de que precisamos para lidar com a variedade inexaurível do sensível.

A ideia de conceito demonstrativo foi introduzida, portanto, para obviar as dificuldades decorrentes da ineliminável limitação de nosso estoque de termos gerais; para nos fazer ver que os recursos do pensamento conceitual são menos restritos do que se pensa ordinariamente e que, se adequadamente entendidos, se mostram tão plásticos quanto o é a experiência. Mais concretamente, isso quer dizer que, quando um sujeito percebe uma tonalidade de cor para a qual não dispõe de um termo geral, o emprego contextualizado da expressão lingüística esta tonalidade recobre a experiência e a incorpora ao espaço das razões, permitindo que imediatamente seja possível inferir, por exemplo, que "esta tonalidade" não é nem vermelho simplesmente, nem púrpura, nem encarnado, nem vermelho-fogo, mas tão só e exatamente esta tonalidade, a qual pode então ser diferenciada não só das demais cores e nuances já batizadas, mas também de qualquer uma outra, como a igualmente ainda inominada aquela tonalidade.

Pois bem, é neste ponto que McDowell observa que para que a expressão demonstrativa possa cumprir essa função é necessário que seja

\footnotetext{
${ }^{3}$ Brewer não utiliza essa expressão que, no entanto, é empregada para designar expressões como essa tonalidade, este formato, etc. Cf. (Lepore e Ludwig, 2000)
}

Manuscrito - Rev. Int. Fil. Campinas, v. 39, n. 3, pp. 199 - 235, jul.-set. 2016. 
satisfeita uma determinada condição, uma condição que é logo especificada como a necessidade de sua retenção temporal, ainda que breve, sem cuja garantia seu caráter conceitual seria duvidoso. A passagem de Mente e Mundo em que esse ponto é explicado diz o seguinte:

Podemos garantir que aquilo que estamos considerando pode ser genuinamente reconhecido como uma capacidade conceitual se insistirmos que exatamente a mesma capacidade de abarcar uma cor na mente pode, em princípio, persistir após a própria experiência. $\mathrm{Na}$ presença da amostra original, 'aquele matiz' pode dar expressão ao conceito de um matiz; o que nos garante que ele é um conceito o que nos garante que os pensamentos que o utilizam guardam a distância daquilo que determinaria sua verdade - é o fato de a capacidade associada ser capaz de persistir no futuro, ainda que seja por um espaço curto de tempo, e que, persistindo, ela também possa ser usada em pensamentos a respeito daquilo que, naquele momento, é passado, ainda que seja apenas um passado recente. $\mathbf{O}$ que está em jogo, aqui, é uma capacidade recognitiva, possivelmente de vida muito curta, que principia com a experiência. (1996, p. 57/2005, p. 95 )

Repare-se que McDowell faz aqui um ponto análogo ao que faz Platão no Menon quando, no curso da discussão sobre a diferença entre opinião e ciência, sustenta que destas a primeira é como são, segundo o mito, as estátuas de Dédalo, as quais, "se não forem amarradas, escapam e fogem; mas, amarradas, ficam", de modo que "possuir uma obra de Dédalo sem têla encadeada é como ter um escravo fujão: é não ter nada (....)."(Menon, 97c-98 $)$. Tomando de empréstimo a imagem e a terminologia platônicas, o primeiro problema a discutir é, pois, o de saber como a amostra original, aquele matiz, para empregar o exemplo standard neste contexto, pode ser amarrada. Contudo, antes de ir adiante é oportuno repisar pelo menos os três seguintes pontos da lição contida no texto que acabamos de citar:

(i) a "presença da amostra original, 'aquele matiz' pode dar expressão ao conceito de um matiz";

(ii) o "que nos garante que" nossa apreensão do matiz em questão "é um conceito (....) é o fato de a capacidade associada [associada ao terse presente a amostra original] ser capaz de persistir no futuro";

Manuscrito - Rev. Int. Fil. Campinas, v. 39, n. 3, pp. 199 - 235, jul.-set. 2016. 
(iii) é essa persistência após a experiência e a resiliência à passagem do tempo da capacidade correlata de tê-la em mente o que faz com que os pensamentos que acompanham e que, num certo sentido, constituem a experiência "guardem distância daquilo que determinaria sua verdade".

Seguindo a terminologia empregada por Platão, o que se deve dizer é que para que este matiz possa adquirir status conceitual é preciso que o caráter tipicamente transiente e fugaz de nossas impressões sensíveis possa ser detido, a corda que neste caso as pode amarrar não sendo, como no âmbito da discussão desenvolvida no Menon, a justificação da crença, mas simplesmente nossa capacidade de retê-las ainda que brevemente.

No entanto, não é nada claro por que simplesmente reter o conteúdo de uma impressão sensível fará dela um conceito. O que é dito na passagem reproduzida em (ii) é que a persistência da capacidade de guardar a amostra original é a garantia da posse pelo sujeito de um conceito demonstrativo. Expressa menos laconicamente, a tese é que a retenção confere ao matiz isolado o caráter conceitual ao permitir e garantir que "os pensamentos que o utilizam" - os pensamentos que, valendo-se da amostra original preservada, a empregam como conceito demonstrativo - "guardem distância daquilo que determina sua verdade". O ponto de McDowell é, pois, que é porque retenho o conteúdo perceptivo deste matiz, que minha representação já não mais está presa e confinada às circunstâncias em que originalmente tive contato direto com ele, o que me permite reaplicá-lo. Além disso, não fosse esse distanciamento, estivesse minha percepção fusionalmente ligada ao percebido, ela poderia ser imediatamente verdadeira ou falsa sem que eu pudesse saber disso, situação que a tornaria imprestável, eis que, em tal hipótese, seria impossível a determinação do valor de verdade dos enunciados em que nos valêssemos de seu conteúdo representacional. ${ }^{4}$ Não será demais insistir, porém, que a retenção aqui relevante não pode ser a recordação cega do matiz, pois o caráter conceitual conferido ao conteúdo retido graças a sua preservação diacrônica depende também de que tal

${ }^{4}$ A propósito, Peacocke observa que conceitos fixam valores semânticos, nesta medida sendo "componentes de conteúdos complexos passíveis de serem avaliados como verdadeiros ou falsos". (Peacocke, in Eric Margolis e Lawrence (eds.) 2000, p. 335).

Manuscrito - Rev. Int. Fil. Campinas, v. 39, n. 3, pp. 199 - 235, jul.-set. 2016. 
conteúdo possa ser utilizado, isto é, que ele possa ser uma segunda vez, diferidamente, posto em jogo e isso não como a repetida, automática e monotônica evocação de uma única e mesma lembrança ${ }^{5}$, mas como um instrumento de reconhecimento de que é ou que não é o mesmo matiz que recorre. No artigo que dedica ao exame da tese de McDowell, Sean D. Kelly propôs que a posse dessa capacidade recognitiva fosse entendida como dependente de uma condição de re-identificação, cuja exigência foi apresentada por ele nos termos seguintes:

(....) para possuir o conceito demonstrativo de X, um sujeito precisa ser consistentemente capaz de re-identificar um dado objeto ou uma dada propriedade como subsumida sob tal conceito, se esse for o caso. $(2001$, p. 403$){ }^{6}$

Em resumo, a ideia subjacente a este ponto é que para que o uso de uma expressão como "esta tonalidade" efetivamente se constitua como conceito é necessário que em vista de apresentações numericamente distintas e temporalmente descontínuas de um perceptum, o sujeito em $\mathrm{T}_{2}$ seja capaz de reconhecer como idênticas à amostra isolada em $T_{1}$ as que lhe forem idênticas e como outras as que não o forem.

\section{A posse dos conceitos ordinários e o tempo}

Agora bem, muito embora as considerações acima sejam mais ou menos claras, a tese principal - a de que o que pode dar expressão conceitual a um matiz demonstrativamente isolado na percepção é a capacidade de retê-lo mentalmente após o momento em que inauguralmente o tivermos identificado - não deixa de trazer alguma surpresa, pois com conceitos comuns não se costuma dizer que para seu emprego as experiências em que

\footnotetext{
${ }^{5}$ A propósito, muito a propósito, veja-se a passagem de Kant na chamada Lógica de Viena cuja referência é dada na nota 25 adiante.

${ }^{6}$ Adiante Kelly acrescenta: "Sob o título 'capacidade recognitiva' entende-se a capaciade de reconhecer, em diferentes ocasiões, a coisa a que o conceito demonstrativo se refere." (Kelly, p. 414.
}

Manuscrito - Rev. Int. Fil. Campinas, v. 39, n. 3, pp. 199 - 235, jul.-set. 2016. 
os adquirimos precisem ser lembradas. Além disso, não é imediatamente evidente como a retenção temporal do apreendido garantiria a sublinhada tomada de distância do ocorrido. Menos ainda por que o sujeito, só por força desse distanciamento, ao valer-se do conteúdo representativo isolado e retido, adquiriria a capacidade de - quando desse uso repetido - controlar o que nessas novas circunstâncias determinaria seu valor de verdade.

Para dar mais um passo no esclarecimento do que está em jogo nessas alegações, creio que é oportuno perguntar: mas essa relação constitutiva da posse dos conceitos demonstrativos com o tempo será exclusiva deles? Ou será que, de algum modo, ela também se verifica no caso dos conceitos comuns? Será que também com relação a estes últimos caberá falar de uma condição temporal a ser satisfeita?

Independentemente da resposta que se venha a dar a essas perguntas, o que neste momento importa da hipótese que acaba de ser levantada é que se, também com relação a conceitos ordinários, couber reconhecer a existência de um vínculo constitutivo de sua posse a uma condição temporal ter-se-á obtido um termo de comparação para entender, contrastivamente, de que modo a condição de posse dos conceitos demonstrativos é determinada. A aposta heurística que estou a fazer sendo, pois, a de que graças a essa contraposição se ganhará um acesso mais fino à especificidade dos conceitos demonstrativos, ao que, em um plano mais fundamental, os extrema dos conceitos ordinários.

A posse de um conceito qualquer, por exemplo, o conceito de cão, pode ser nosso ponto de partida nessa exploração. Suponhamos que em nossa infância o tenhamos adquirido e que, anos passados, por força de uma ou outra causa de deterioração de nossas faculdades superiores, o tenhamos esquecido. À primeira vista, a superveniência dessa alteração em nossas capacidades não tem qualquer incidência sobre as condições estruturais de acesso a e de posse do conceito de cão, pois é perfeitamente óbvio que se eu for acometido do mal de Alzheimer e esquecer o que é um cão, isso em nada alterará o fato de que, durante décadas, intacta minha capacidade neuronal, eu pude possuí-los perfeitamente. Também muito evidente é que quem dispuser plenamente do conceito sortal de cão não precisa nem se lembrar de como o adquiriu, nem recordar ocasiões pretéritas em que dele fez uso, o esquecimento da história da posse conceitual e de suas origens contextuais sendo irrelevante. Portanto, pelo menos à primeira vista, a posse

Manuscrito - Rev. Int. Fil. Campinas, v. 39, n. 3, pp. 199 - 235, jul.-set. 2016. 
de um conceito ordinário, de um sortal como o conceito cão, não parece ter nada a $\operatorname{ver}^{7} \mathrm{com}$ a capacidade de lembrar das circunstâncias relativas à sua aquisição e muito menos ainda com a capacidade identificar suas instâncias como sendo exatamente coincidentes com um objeto, ou propriedade, paradigmaticamente apreendidos na situação em que originalmente $o$ adquirimos. Sob este aspecto não cabe duvidar, portanto, que a posse de conceitos ordinários seja indiferente ao tempo.

Contudo, mesmo assim, não parece impertinente perguntar: pode alguém possuir o conceito de cão se não lembrar nem de como o adquiriu, nem recordar os usos que anteriormente fez desse conceito? Para melhor apreciar o interesse dessa pergunta convém desconsiderar os casos em que a pessoa em questão teria esquecimentos parciais, mas preservaria as notas principais do conceito de cão, e indagar o que ocorreria em um caso de amnésia mais grave, um caso em que o sujeito, mesmo que diretamente inquirido não fosse capaz de enunciar as características mais banais que costumamos atribuir aos cães, mas que, contudo, a despeito dessa impotência para explicitar o sentido da palavra cão, ao cruzar com algum cão, fosse eventualmente ainda capaz de dizer: que cão bonito, ou cuidado com o cão, etc.

Ora, como, em tal caso, se haverá de entender a posse por um tal amnésico do conceito de cão? $O$ mais natural parece ser admitir que o conceito de cão teria sido preservado exclusivamente como uma enactive representation, para empregar com alguma liberdade o termo de Jerome Bruner (Bruner, 2006, p. 69), o encontro eventual com o cão tendo reativado pontualmente a faculdade de reconhecer a cães, a qual, contudo, já não seria mais passível de evocação espontânea, nem de articulação verbal, de sorte que embora ainda empregável em termos estritamente de $r e^{8}$, ao ensejo incidental de novos encontros com cães, o conceito correspondente seria possuído subdoxasticamente, sem consciência de posse. Inobstante isso, é inequívoco que, mesmo nesta última situação, a capacidade de reconhecer cães é dependente de que o conceito de cão tivesse sido, de uma

\footnotetext{
${ }^{7}$ Este é um ponto feito com clareza por Philippe Chuard (2006).

${ }^{8}$ Estamos seguindo aqui uma sugestão de Chuard, de acordo com a qual "O que é crucial para a re-identificação de re é que o sujeito não precisa ser consciente de que o que ele assim re-identifica é o mesmo." (2006, p. 168).
}

Manuscrito - Rev. Int. Fil. Campinas, v. 39, n. 3, pp. 199 - 235, jul.-set. 2016. 
ou outra forma, retido, sendo satisfeita, por conseguinte, o que talvez se possa chamar uma condição temporal geral de aplicação de conceitos. Essa condição pode ser expressa, de maneira vaga e quase tautológica dizendo-se que terá posse de um conceito comum quem for capaz de aplicá-lo a objetos ou propriedades que sejam suas instâncias.

Bem entendido, a aceitação dessa condição implica a recusa a admitir que a dita posse deferencial dos conceitos seja não letalmente defectiva, ponto que não pretendo considerar aqui. $\mathrm{O}$ que importa para a discussão presente é que se a posse de conceitos comuns pode ser dispensada da condição de re-identificação, daí não se segue que ela se desvencilhe de toda vinculação ao tempo; que, mais especificamente, esteja livre da necessidade de ser temporalmente preservada e que, assim, esteja liberada do que acabei de denominar a condição temporal geral de aplicação.

Nesta altura um objetor eventual poderia perguntar: Mas que interesse há em sublinhar essa banalidade? O que têm a ver essas distinções empíricas sobre casos mais ou menos graves de deterioração psicológico-cognitiva com a discussão da questão filosófica que vínhamos encetando? A objeção parece sensata e a pergunta plausível. No entanto, a verdade é que ela mostra que quem a faz não entendeu de que modo compreender o que é esquecer um conceito contém a explicação para o que é dispor de um conceito. Um primeiro expediente para tornar mais claro o que estou sugerindo talvez seja dizer que embora a posse de conceitos esteja sujeita às variações empíricas dos incontáveis casos de retenção e esquecimento, isso é irrelevante porque, parafraseando uma fórmula de Anton Ford, "no caso decisivo, naquele por relação com o qual cada posse de conceito é um caso", a retenção do conceito é constitutiva e é com relação a essa determinação essencial que se pode falar de casos de não posse e de aquisição e esquecimento dos conceitos. Creio que o argumento a seguir demonstra suficientemente essa alegação.

Considere-se a situação em que um sujeito fosse portador de uma disfunção cognitiva diferente e mais grave do que a anteriormente mencionada, uma disfunção que fizesse com que, embora apresentado a um

\footnotetext{
${ }^{9}$ Parafraseamos e transpomos para o contexto presente uma análise de Anton Ford dedicada a explicar como a ciência do agente do que está a fazer é constitutiva das promessas (2011, p. 101)
}

Manuscrito - Rev. Int. Fil. Campinas, v. 39, n. 3, pp. 199 - 235, jul.-set. 2016. 
cão e conquanto capaz de receber uma explicação de que se trata de uma espécie animal provida de tais e quais características, tão logo concluída esta última e voltada sua atenção novamente ao cão, perguntasse: mas o que é isso? Em uma situação como essa - que podemos denominar de situação do Sísifo conceitual e que se caracterizaria pelo fato de que a cada aparição de um indivíduo da espécie Canis tornar-se-ia necessário novamente apresentar o cão e ensinar ao sujeito o que é objeto o que lhe está anteposto aos olhos - a conclusão epistêmica que devemos tirar não é a de que tal indivíduo esqueceu a cada vez o conceito de cão, mas, antes, a de que jamais o possuiu. Repare-se que a razão mais importante para sustentar que o sujeito em questão jamais adquiriu o conceito de cão é que o schibolleth da posse conceitual está é na capacidade de identificar as instâncias do conceito.

Não parece razoável duvidar, portanto, de que um análogo da "condição de McDowell" se aplica também a conceitos sortais e caracterizadores e que não se pode admitir a posse de tais conceitos nos casos em que o sujeito for incapaz de reter - ainda que somente disposicional e não articuladamente o critério de discriminação do que pode e do que não pode vir a ser admitido como instância do conceito. A evidência da retenção dessa regra que não implica que o sujeito a tenha explicitamente em sua consciência, nem que seja capaz de expressá-la articuladamente - é patenteada, no exemplo que estamos examinando, pelo malogro do exercício da capacidade de identificar exitosamente um cão quando do emprego referencial da palavra cão. ${ }^{10}$

Sendo assim, estabelecida a relação necessária da posse dos conceitos ordinários com o tempo e, mais especificamente, a necessidade de que ela seja de algum modo prolongada, o inquérito que é preciso fazer, em vista dos fins perseguidos neste texto, é se é essa mesma dependência de

10 É claro, no entanto, como se verá adiante, que a retenção meramente disposicional de conceitos não demonstrativos, não pode ser equiparada à condição de re-identificação proposta por McDowell, e reforçada por Kelly, uma vez que aquela não implica que quem detenha o conceito tenha que trazer o próprio conteúdo do conceito em mente, que tenha que poder contemplá-lo, para usar a expressão de McDowell, com os olhos da mente a fim de poder cotejá-lo com suas instâncias, ou com pretendentes a tanto que não podem ser confirmados. (Cf., 1996, p. 173/2015, p. 94 e nota 37 infra).

Manuscrito - Rev. Int. Fil. Campinas, v. 39, n. 3, pp. 199 - 235, jul.-set. 2016. 
extensão temporal a que se deve reconhecer como própria dos conceitos demonstrativos.

\section{A posse dos conceitos demonstrativos e o tempo}

A pergunta que cabe agora responder é, portanto, a seguinte: mas o que, mais exatamente, distingue as duas condições a que acabamos de nos referir, as ditas (i) condição temporal geral de aplicação e (ii) condição de reidentificação?

Se, começando pela primeira, perguntarmos pelas condições de aplicação dos conceitos comuns, devemos preliminarmente distinguir dois planos em que a questão pode ser colocada: um plano pragmático e psicológico e um plano semântico e normativo. Isto quer dizer, no primeiro desses planos, que para aplicar um conceito um sujeito qualquer precisa primeiramente ter mnemonicamente retido o conceito - seja explícita e discursivamente, seja disposicionalmente- encontrando-se, assim, em estado de prontidão para valer-se dele em circunstâncias apropriadas, ainda que falivelmente.

No entanto, não é difícil ver, o segundo desses requerimentos contém um elemento normativo que remete à segunda dimensão da análise, às propriedades semânticas dos conceitos, pois exige que o sujeito que venha a aplicar denotativamente um conceito seja capaz de identificar o que faz e o que não faz parte da extensão dele e isso não é algo que o sujeito tome, ou que possa tomar, como dependendo de seu arbítrio. Sendo assim, no caso dos conceitos comuns, a retenção da palavra que expresse o conteúdo conceitual, embora empiricamente necessária, é semanticamente secundária, pois o decisivo com relação ao emprego dos conceitos é a posse pelo sujeito de uma regra de determinação do universo extensional do conceito a ser empregado. ${ }^{11}$ A questão crítica com relação à determinação da condição de posse dos conceitos comuns não diz respeito, portanto, ao modo contingente como conceitos são adquiridos e esquecidos, mas sim (i)

11 Christopher Peacocke propõe que se denomine o que denominei de universo extensional de "range of significance", recomendação que ele introduz dizendo: "Será conveniente rotular o domínio [range] de objetos dos quais um dado conceito é verdadeiro ou falso, de seu 'domínio [range] de significação". (1992, p. 42).

Manuscrito - Rev. Int. Fil. Campinas, v. 39, n. 3, pp. 199 - 235, jul.-set. 2016. 


\section{à determinação do estatuto de uma tal regra de determinação extensional e (ii) do modo como tal regra é retida nos casos que o sujeito detém o conceito.}

Repare-se que se adotarmos uma concepção naturalista dos conceitos esse complexo de problemas parece simplificar-se muito, pois, em vez de uma regra, ter-se-á uma lei que associará causalmente certos estados do mundo a certos estados mentais, a condição de retenção dessa lei passando assim a ser função do bom funcionamento cerebral do sujeito que estiver sendo considerado e das condições ambientais em que o conceito estiver sendo empregado. No entanto, parece prudente deixar de lado essa via de simplificação do problema, pois ela cria novas e não menores dificuldades, a mais importante das quais sendo a de que, se a admitirmos, fica ipso facto interditada a admissão de erros no sentido crítico usual da palavra, o sentido desse termo tendo que ser então reduzido ou ao de patologias neurológicas, ou ao de falhas funcionais, ou ao de anomalias ambientais, em qualquer dessas hipóteses ficando excluído o caráter propriamente normativo dos conceitos e a possibilidade de, em alguma medida, responsabilizar a quem, fazendo mau uso deles, vier a produzir juízos falsos. ${ }^{12}$

Seja como for, nesta altura podemos já dizer que o estatuto da regra de determinação extensional dos conceitos é modalmente condicionada pela possibilidade de aplicação de qualquer conceito a um espectro indeterminado de instâncias, aplicação de cuja adequação dependerá o valor de verdade dos enunciados em que o conceito vier a ser utilizado. No entanto, se recusarmos a encontradiça posição de que o conteúdo dos conceitos é redutível, na verdade idêntico, ao exercício da capacidade de empregá-los adequadamente, posição equivalente a munchausiana história de arrancar-se da areia movediça puxando os próprios cabelos, restará por esclarecer como é determinada a regra de adequação de tal emprego, a qual, classicamente, foi denominada "compreensão" ou "intensão" dos conceitos. Ou, por outra: restará por explicar o estatuto normativo de cada conceito e que faz com que, para dar um exemplo qualquer, o conceito CAVALO seja

12 Claude Panaccio aponta que esse problema se coloca agudamente para Fodor, pois se a relação intencional for reduzida à relações causais, não pode haver pensamentos falsos em condições normais. (Panaccio, 1991, p. 108-109).

Manuscrito - Rev. Int. Fil. Campinas, v. 39, n. 3, pp. 199 - 235, jul.-set. 2016. 
conceito de cavalos, não de asnos, independentemente da língua que se estiver a falar ou da maior ou menor frequência com que esses animais vierem a ser confundidos.

Pois bem, creio que para melhor analisar este ponto, para fins de esclarecimento do modo como é determinado o conteúdo intensional dos conceitos, será útil mudar de paisagem doutrinária e, bem alternativamente, nos deixarmos guiar pela lição de Kant. Fazendo-o, o que se poderá imediatamente dizer é que tal determinação ocorre graças à consciência não necessariamente autoconsciência atual - por parte de quem quer que venha a empregar o conceito de que uma, ou algumas mesmas características estão presentes em várias representações. $\mathrm{Na}$ chamada "Metafísica Mrongovious" este ponto é apresentado assim:

Um conceito é a consciência de que o [mesmo] está contido em uma representação assim como em uma outra, ou que em múltiplas representações uma e mesma característica está contida. Isto pressupõe consciência ou apercepção. Os animais (....) comparam representações umas com as outras, mas não são conscientes de onde jaz a harmonia ou a desarmonia entre elas. (....) Mas como os conceitos são possíveis mediante a apercepção? Em que eu represento para mim próprio a identidade de minha apercepção em múltiplas representações. O conceito é uma percepção comum <perceptivo communis>, por exemplo, o conceito de corpo. Este aplica-se ao metal, ao ouro, a pedra, etc. Nele eu represento o um em um múltiplo. A função lógica dele consiste na generalidade.(AA, 29, pp. $888-889$ / 1997, p. 257$)^{13}$

$\mathrm{Na}$ "Lógica de Viena" encontra-se uma ilustração mais simples deste ponto, desta vez o exemplo escolhido sendo o do conceito de VERMELHO. Lê-se ali:

${ }^{13}$ Repare-se que de acordo com a análise de Kant o que está em jogo aqui é completamente diferente do que ocorre com relação a palavra ouro e isso porque no caso da relação dos conceitos com aquilo de que são conceitos a ligação entre ambos não é arbitrariamente convencional, mas se constitui como uma relação interna entre o conceito e aquilo de que ele é conceito. O caráter interno dessa relação determina-se, por sua vez, pelo que Kant denomina a homogeneidade que á há entre os conceitos comuns e aquilo de que são conceitos.

Manuscrito - Rev. Int. Fil. Campinas, v. 39, n. 3, pp. 199 - 235, jul.-set. 2016. 
Aquele que quiser ter uma representação da cor vermelha primeiro tem que ver a cor vermelha. Quando ele compara a cor vermelha no vermelho do cinábrio, do carmim, do encarnado, ele se torna consciente, contudo, de que há algo geral na cor vermelha, que está contido junto com outras coisas em outras representações dessa cor e ele pensa que o vermelho é isso que é comum a vários objetos e que esse é o conceito dele. Um conceito, então, é a representação do que é comum a várias coisas. (AA, 24, pp. 904-905 / 1992, pp. 348-349) ${ }^{14}$

Colocada em termos contemporâneos, a posição de Kant pode ser expressa dizendo-se que:

$\boldsymbol{I S}$ [a intensão de um conceito] é determinada pela capacidade do sujeito que o empregue de dar-se conta que uma propriedade $\boldsymbol{p}$, instanciada por um objeto $\boldsymbol{o}$ em um contexto $\boldsymbol{c}$, é a mesma que um objeto $\boldsymbol{o}$ 'instancia em um contexto $\boldsymbol{c}^{\boldsymbol{\prime}^{15}}$

Agora bem: o reconhecimento de que $\boldsymbol{p}$, instanciada em $\boldsymbol{o}$, é a mesma $\boldsymbol{p}$ vista como instanciada em $\boldsymbol{o}$ dependerá da lembrança dessa visão ocorrida em $\boldsymbol{c}$ ? Ou, mais simplesmente: dar-se conta que $\boldsymbol{p}$, instanciada em $\boldsymbol{o}$, é a

14 Comentando a tese kantiana, o Professor Luciano Codato observa esclarecedoramente: "Na origem dos conceitos empíricos encontra-se uma operação que passa do ver 'algo em algo' para o pensar 'algo sob algo', mediante a consciência da universalidade, isto é, da validade comum." (2011, p. 123)

${ }^{15}$ Não é possível examinar mais extensamente aqui as condições subjacentes à essa possibilidade de reconhecimento do que há de comum, por exemplo, nas diferentes amostras de ouro, cobre, prata, etc. Registre-se simplesmente que ela depende simultaneamente de que o sujeito seja capaz de (i) distinguir identidades e diferenças; (ii) separar um sujeito de suas propriedades; (iii) transformar itens icônicos, sensíveis no sentido estrito do termo, os predicados da intuição, na terminologia de Kant, em notas características cujo estatuto é lógico, convindo observar que esta última capacitação, como Kant assinala no capítulo sobre o esquematismo, é "uma arte oculta nas profundezas da alma humana, cujo segredo de funcionamento dificilmente poderemos alguma vez arrancar à natureza" (A 141/B 180).Prognóstico este, permitam-me observar en passant, que, aliás, não tem desencorajado os esforços da ciência cognitiva contemporânea.

Manuscrito - Rev. Int. Fil. Campinas, v. 39, n. 3, pp. 199 - 235, jul.-set. 2016. 
mesma $\boldsymbol{p}$ que fora vista instanciada em $\boldsymbol{o}$ será uma lembrança? Creio que a resposta terá que ser negativa, e isso não só porque, como nota Husserl, tal retenção não é a memória de algo passado, mas, mais radicalmente, porque, a seguir-se ainda a indicação de Kant, ao comparar o vermelho do cinábrio, do carmim, do encarnado o sujeito terá apreendido o que há de comum entre eles, de modo que a relação que o sujeito vier a ter com as propriedades de $\boldsymbol{o}$, de $\boldsymbol{o}$ ”, ou de $\boldsymbol{o}^{\boldsymbol{n}}$ ' em circunstâncias $\boldsymbol{c}, \boldsymbol{c}$ ”, ou $\boldsymbol{c}^{\boldsymbol{n}}$ estará informada e condicionada pela posse desse elemento comum, não pela lembrança do acesso aos conteúdos representacionais mais determinados, em nosso exemplo, aqueles respectivamente hauridos nos encontros perceptivos com o cinábrio, o carmim e o encarnado. Este é manifestamente o sentido preciso em que nas doutrinas clássicas do conceito sempre foi dito que eles são gerais e abstratos: gerais porque se aplicam a um rol indeterminado de casos; abstratos porque irredutíveis a qualquer dos casos ou instâncias a que se apliquem. Colocando o ponto em termos mais estritos, o que cumpre admitir é que o regime lógico da identificação de uma instância de um dado conceito nunca será o de um reconhecimento, pois, categorialmente, há um abismo entre conceito e instância, uma não identidade categorial que os torna em certo sentido incomensuráveis. O mesmo que quem possui o conceito de vermelho vê no cinábrio, no carmim e no encarnado não está em nenhum deles que, por si sós, são justamente cinábrio, carmim, encarnado. Entende-se assim porque a descontextualização é um requisito e traço constitutivo dos conceitos comuns.

Com requerida vênia dos colegas analíticos, creio que no que se está a dizer aqui há algo análogo ao que Derrida diz próprio do que denomina de suplemento, a saber: que "se o conceito representa e faz imagem ele o faz pela ausência de uma presença anterior." (Derrida, 1973, p. 178). Como se acaba de ver, esta, de resto, é a razão pela qual quem possui um conceito ordinário não só pode desligar-se da origem dele, mas tem que livrar-se das experiências singulares que tenham estado na origem de sua aquisição. Kant, o incomparável Kant, expressou clara, aguda e convincentemente este ponto ao dizer:

Se eu não pudesse abstrair, então não teria conceito algum, porque algo de outro do que o que é comum às representações individuais sempre me estaria a ocorrer. Por exemplo: fosse alguém de tal jeito

Manuscrito - Rev. Int. Fil. Campinas, v. 39, n. 3, pp. 199 - 235, jul.-set. 2016. 
que, dada a expressão casa, o que sempre lhe ocorresse fosse a taberna que ele havia visto, então ele preservaria sempre um intuitus. (AA, 24, p. 909 / 1992, 353)

Esta é também a razão pela qual a dependência da posse de tais conceitos do tempo, cuja necessária vigência defendi acima, concerne à memória conceitual, ou proposicional, como se costuma preferencialmente dizer; concerne à retenção da regra de identificação das instâncias, não à lembrança icônica de qualquer dos casos que originalmente serviram para a formação dos conceitos. A consideração de um caso de amnésia mais grave do que o analisado acima, um caso em que nos defrontemos com um sujeito que nem mesmo de re e ocasionalmente seja capaz de reconhecer como cão ao cão que estiver interagindo com ele, torna o ponto mais claro, pois em tal caso o que o sujeito perdeu não foi somente a lembrança dos cães com os quais teve ocasião de interagir preteritamente, mas foi antes e decisivamente o elemento comum de que dispõe quem possui o conceito de cão e que é o requisito necessário para a identificação como cães de quaisquer cães. Pode-se agora tornar mais precisa a condição temporal de aplicação dos conceitos ordinários dizendo que:

Um sujeito $S$ terá posse de um conceito $C$ na medida em que, retendo a representação do que é comum na variação das instâncias de C, for capaz de: (i) preservar a representação desse elemento comum EC; (ii) valer-se de EC para aplicar C, positiva ou negativamente, a objetos ou propriedades com os quais venha a interagir, ainda que falivelmente.

Mas cabe agora perguntar: será desta mesma maneira que funcionam também os conceitos demonstrativos? Será desta mesma maneira que os conceitos demonstrativos estarão temporalmente condicionados?

Para responder a estas questões convém começar observando que já pelo modo como McDowell introduz a noção de conceito demonstrativo - sua indicação de que para adquiri-lo é necessário aproveitar-se da amostra parece claro que, de maneira inteira e radicalmente diferente do que ocorre no caso dos conceitos ordinários, o conteúdo do conceito demonstrativo absolutamente não pode ser descolado de suas condições de aquisição, pois, como já visto, o conceito neste caso se constitui justamente 
graças à amarra que prende o conteúdo da experiência perceptiva, pois é essa detenção que permite sua integração ao domínio conceitual e que o converte em conteúdo do conceito demonstrativo que sua retenção permitiu formar. Como diz expressamente Brewer na passagem citada no início dessa conferência, o caráter distintivo dos conceitos demonstrativos provém, assim, de que, graças a eles, podemos abandonar a ideia de que representações conceituais são necessariamente descontextualizadas.

É fundamental precisar, porém, a natureza muito particular do enraizamento contextual dos conceitos demonstrativos e notadamente observar que eles não são contexto-dependentes no mesmo sentido em que o são os demonstrativos propriamente ditos, cuja reaplicação, se tornada possível pela estabilidade do caráter, para usar a linguagem de Kaplan, não implica a preservação do conteúdo das demonstrações feitas por meio deles. Muito pelo contrário, o próprio dos demonstrativos e, em geral dos termos indexicais, é justamente a labilidade contextual de seus conteúdos, ou, para usar a terminologia de Quine e introduzir um anglicismo: a transiência da referência. (Quine, 1999 (1960), p. 101)

Conceitos demonstrativos, no entanto, de acordo com a análise de McDowell, fixam os conteúdos apreendidos nos contextos em que foram formados. E, neste sentido, talvez se possa dizer que se aparentam antes aos nomes. No entanto, essa aproximação também é enganosa, pois não só a aplicação do nome próprio independe de qualquer gesto indicativo, como nota Wittgenstein (1958, p. 21), como também, conforme a análise clássica de Kripke, ela é determinada pela transmissão da relação estabelecida no batismo, enquanto que este matiz tem suas condições de aplicação determinadas, como logo se verá, pela retenção do conteúdo de uma dada experiência e pelas relações de equivalência icônica entre o conteúdo mental haurido quando do contato original com a amostra e seus casos de aplicação. Isto implica que a posse por um terceiro de um conceito demonstrativo como 'este matiz' depende de que esse interlocutor tenha de algum modo acesso a conteúdo dado por outrem a essa expressão em um contexto determinado. O que exige que ele tenha acesso a algum tipo de amostra, sem o qual o mero proferimento da expressão será semanticamente vazio e inerte.

Acrescente-se ainda que por razões análogas, a semântica e a pragmática de um conceito demonstrativo no sentido de McDowell, embora muito 
próximas, tampouco se igualam as que Quine diz serem próprias dos por ele denominados termos singulares demonstrativos. Com efeito, de acordo com a explicação destes últimos oferecida em Word and Objects,

Os termos singulares demonstrativos preservam o mecanismo da ostensão (....) ao mesmo tempo em que poupam o processo de treinamento que ocorre no ensino de 'mama' e de 'água'. Os termos gerais assim explorados precisam primeiramente ser aprendidos e o aprendizado deles é, como observado ( $(19)$, uma questão mais elaborada do que o aprendizado de 'mamãe' ou de 'água'. Mas, uma vez realizado, eles abrem espaço para a introdução ostensiva em alta velocidade de singulares, seja temporários (este rio, esta mulher), seja permanentes ('o Nilo', 'Nadejda'). (1999 [1960], p. 102).

Uma primeira diferença a ressaltar é que enquanto a Quine o que importa é o uso do termo geral para desambiguar e dar velocidade e segurança à individualização ostensiva de objetos e propriedades, a McDowell o que interessa, muito diferentemente, é mostrar como a introdução de um termo singular por meio de uma expressão demonstrativa complexa pode ser meio para a formação e a fixação de um conceito. É verdade que Quine diz que, uma vez adquiridos, esses "termos singulares derivados facilitam, por sua vez, a introdução ostensiva de novos termos gerais", função que sem nenhuma dúvida McDowell admitiria como exercível pelos conceitos demonstrativos. A diferença principal das duas análises de expressões enunciativamente idênticas é que para McDowell o que importa não é tomar 'este matiz' como uma instância do conceito MATIZ, como uma maneira expeditiva de poupar uma descriação definida, mas antes destacar que a introdução de uma expressão como esta cria um conceito novo, cuja peculiaridade é a de ser geneticamente dependente, amarrado a sua origem.

Nesta altura, contudo, parece-me importante registrar que, com relação à explicação de como tem lugar a formação do conceito demonstrativo e ao modo como o conteúdo da experiência perceptiva ganha estatuto conceitual, nem as análises de McDowell, nem as de Brewer o fizeram de modo suficiente, de modo que o que mais me importa é tentar conferir maior precisão ao exame dessa questão.

Manuscrito - Rev. Int. Fil. Campinas, v. 39, n. 3, pp. 199 - 235, jul.-set. 2016. 
Para fazê-lo creio que o primeiro registro a fazer é o de que a formação de conceitos demonstrativos exige que se admita que esta tonalidade tem uma forma de universalidade sui generis, uma universalidade que deve ser considerada como semanticamente unívoca e extensional e ontologicamente uniforme, uma vez que o que o conceito demonstrativo permite fazer é determinar a equivalência icônica estrita das ocorrências daquilo de que o conceito demonstrativo é conceito com seu próprio conteúdo intensional, excluídas, portanto, tanto a diferença ontológica radical, típica dos conceitos gerais, entre eles e suas instâncias, quanto o regime de entrelaçadas semelhanças que caracterizam a estas últimas. ${ }^{1617}$ Em segundo lugar, convém também marcar os pontos analiticamente obtidos até aqui e que são os seguintes:

(i) o conteúdo de uma expressão demonstrativa constituída como um conceito demonstrativo deve ser entendido, para expressar o ponto com ajuda da terminologia proposta por Perry, como um "loyal

16 Ao introduzir sua concepção de univocidade Deleuze diz: "É da essência do ser unívoco reportar-se a diferenças individualizadoras, mas essas diferenças não tem a mesma essência, e não variam a essência do ser - como o branco se reporta a intensidades diversas, mas permanece essencialmente o mesmo branco." (1972, p. 53). Ora, o que se pretende apreender por meio do conceito de conceito demonstrativo é um caso em que as diferenças individualizadoras, para usar o jargão de Deleuze, têm a mesma essência e são qualitativamente idênticas, sua diferença sendo externa, resultado da dispersão espacial e/ou temporal.

${ }^{17}$ É verdade que se se tomar 'matiz' na expressão 'este matiz', não como um termo geral, mas como o que Quine chama de termo de massa, como é água, ou vermelho, a distância de sua análise da de McDowell diminui, porque estes termos, segundo sua análise, têm a propriedade semântica de referirem cumulativamente, de modo que a dispersão material de suas ocorrências é externa e semanticamente irrelevante, pois 'água' fará referência à água, quer se encontre no leito de um rio, em um lago, ou correndo de uma torneira. Todavia, mesmo com este ajuste, a inovação de McDowell continua distante da análise de Word and Object, pois o que importa a Quine quando da consideração dos casos em que um termo de massa está em posição predicativa é que ele deve aí ser tomado como um termo geral, pois sua função em tais usos é a mesma que a cumprida por estes últimos quando igualmente pospostos à cópula em expressões que tenham um demonstrativo em posição de sujeito: a de excluírem a qualquer possível equivocidade da ostensão. ((1999 [1960], pp. 103-104)

Manuscrito - Rev. Int. Fil. Campinas, v. 39, n. 3, pp. 199 - 235, jul.-set. 2016. 
character", que apresenta o mesmo conteúdo, em qualquer contexto; não como um "flighty character", que nos dá conteúdos diferentes em contextos diversos. (Cf. Perry, 2000, p. 357 e 364.);

(ii) muito embora os conceitos demonstrativos tenham a generalidade como um de seus traços constitutivos, eles não possuem a segunda característica própria dos conceitos comuns: a de serem abstratos, pois, no caso deles, não há a diferença categorial entre conceito e instância que apontamos acima como própria destes últimos;

(iii) sua função, diferentemente da dos termos singulares demonstrativos de Quine, não é acelerar e garantir o processo de individualização ostensiva dos objetos a que se quiser fazer referência, mas a de estabelecer um padrão para identificação de uma certa qualidade.

Se agora, seguindo um dito conhecido, para avançar dermos um passo atrás e tratarmos de precisar positivamente como os conceitos demonstrativos são contextualmente determinados, a resposta deverá ser a de que eles são superdeterminados, que há neles um visgo que os cola a seus contextos de origem. Ou, para já não falar metaforicamente, o que é preciso reconhecer é que uma condição necessária para fixar o conteúdo deles é que este tenha sido determinado por quem inauguralmente os empregue como rigidamente fixado pelo contexto em que tiverem sido formados.

Admitido este ponto, cabe, contudo, perguntar: pois bem, fixado, então, o conteúdo do conceito demonstrativo, como o conceito assim formado pode relacionar-se com aquilo de que é conceito? Dever-se-á dizer que ele, como qualquer outro conceito, tem instâncias? Por certo, enquanto conceito, sua razão de ser é poder ser aplicado e reaplicado, mas, repetindo, aquilo a que os conceitos demonstrativos se aplicam pode ser denominado e considerado como instâncias deles? Para que essas perguntas se tornem menos estranhas lembre-se que não se costuma dizer que a cada vez que um termo indexical é empregado a ocorrência desse termo é uma instância dele. Não é usual dizer que em expressões como esta casa, este livro 'este' seja uma instância do demonstrativo ESTE, ponto que justifica que não se iguale tokens a instâncias. Levando isso em conta, no caso dos conceitos demonstrativos no sentido de McDowell como se haverá de determinar sua relação com os casos em que são aplicados?

Manuscrito - Rev. Int. Fil. Campinas, v. 39, n. 3, pp. 199 - 235, jul.-set. 2016. 


\section{Condições e estatuto do emprego dos conceitos demonstrativos: a inconsequência de Mcdowell}

Mais uma vez, a condição para ir adiante requer tomar apoio em um ponto já visto, retorno que neste caso consiste em voltar a nosso termo de contraste e repisar que de acordo com a Lógica da avó, para tomar emprestada uma expressão de Fodor, a determinação epistêmica da extensão dos conceitos baseia-se em suas respectivas compreensões, ou, como se tem preferido dizer, em sua intensões. É sabido que essa concepção encontra problemas de várias ordens ${ }^{18}$, mas para os fins da comparação que aqui nos importa fazer, o relevante é sublinhar que conceitos demonstrativos como esta cor não são internamente estruturados dessa maneira. No caso deles o que ocorre é que a determinação do conteúdo conceitual se faz por meio da fixação de uma regra de exemplaridade, mediante a qual uma evidência perceptiva indexada a uma experiência é transformada em uma amostra por referência à qual se decidirá pela inclusão ou de exclusão dos casos da extensão do conceito assim criado. ${ }^{19}$ A consequência é que as condições de

$18 \mathrm{O}$ mais conhecido desses problemas é a impossibilidade - no caso de conceitos conhecidos e comuns - de que os membros da extensão do conceito satisfaçam todos o mesmo conjunto de notas que compõem o conceito. Desde as análises clássicas de Wittgenstein sobre o conceito de jogo este ponto se tornou um lugar comum. Outra dificuldade é a colocada pelos casos limites, como ocorre com os conceitos de cores. Outra ainda é o problema da ignorância dos elementos constitutivos do conceito, que não parece ser um óbice maior a seu uso adequado, como se pode ver em casos como o do conhecido emprego do conceito de varíola muito antes que a etiologia da doença tivesse sido elucidada e muito antes, portanto, de que se tivesse qualquer noção clara das condições necessárias e suficientes de emprego do conceito. Com relação à toda essa problemática veja-se o livro organizado por Margolis e Laurence já citado. Sobre o exemplo da varíola cf. Margolis e Laurence, 2000, p. 21.

19 Seríamos tentados a dizer: indexada a uma experiência e a suas respectivas coordenadas espaço-temporais, mas isso seria um erro grave, pois McDowell expressamente exclui essa ampliação das condições de admissão dos conceitos demonstrativos ao dizer: "O tipo de pensamento que tenho em vista aqui deve ser distinguido de um outro que poderia ser expresso por algo como: 'Gostaria que as paredes de meu quarto fossem pintadas com o matiz de rosa que vi em tal ocasião'.

Manuscrito - Rev. Int. Fil. Campinas, v. 39, n. 3, pp. 199 - 235, jul.-set. 2016. 
aplicação dos conceitos demonstrativos são determinadas por relações de equivalência entre o conteúdo fixado originalmente e os casos em que o sujeito que os possua se veja obrigado a valer-se dele para decidir sobre a identificação ou não de uma nuance, para ficar com o exemplo paradigmático.

No entanto, malgrado essa análise, cabe ainda perguntar: mas como a amostra isolada demonstrativamente adquire caráter conceitual? Minha resposta, e isso é o decisivo, é que a conversão da amostra apreendida perceptivamente em conceito - conversão mediada pelo emprego da expressão demonstrativa complexa - depende da transformação do conteúdo da amostra em padrão. ${ }^{20}$

No entanto, antes de tentar esclarecer diretamente o que vai envolvido nessa tese, parece-me crítico e absolutamente indispensável entender que o universo da generalidade, conforme uma fina lição de Gilles Deleuze, subdivide-se em duas ordens: a ordem qualitativa das semelhanças e a

Alguém poderia ter um pensamento desse tipo sem trazer à lembrança (como naturalmente podemos dizer) o próprio matiz. É possível que nos lembremos de que se tratava de um matiz de damasco, só que mais claro, e que nos marcou por ser ideal para as paredes de nosso quarto. No caso que me interessa, alguém traz o próprio matiz em mente (como naturalmente podemos dizer): o matiz figura no nosso pensamento apenas como algo que satisfaz certa especificação. Um modo de capturarmos essa ideia é dizer que vemos aquele matiz com os olhos da mente." (1996, p. 173/2005, p. 215).

${ }^{20}$ Nelson Goodman cogita dessa opção para determinação da identidade de cores quando diz: "Se se sustentar que a comparação de apresentações temporalmente diversas não tem sentido [is meaningless], então segundo tal teoria a distinção entre propriedades e mudanças de propriedades também se tornarão sem sentido. Podese tentar delinear essas distinções de uma nova maneira dizendo que atribuir uma propriedade a um objeto é simplesmente afirmar que, quando comparado com certos objetos-padrão, o objeto dado apresenta uma qualidade [quale] que mantém uma especificada relação (por exemplo: é ajustada a [matches], é complementar a, etc) com a qualidade apresentada pelo objeto padrão." (1977, p. 97). É verdade que Goodman imediatamente acrescenta que "o problema é que não há objetos-padrão, não há objetos que consideremos como cromaticamente imutáveis e incambiáveis." (1977, pp. 97-98). Adiante, no entanto, Goodman admitirá e estabelecerá os princípios a serem seguidos no mapeamento de qualidades [qualia]. Cf. ob. cit., capítulo IX, notadamente seção 3.

Manuscrito - Rev. Int. Fil. Campinas, v. 39, n. 3, pp. 199 - 235, jul.-set. 2016. 
ordem quantitativa das equivalências.(1968. P. 7) Nos dois casos, um termo pode ser atribuído a particulares que podem ser substituídos, mas, no primeiro caso, a regra de aplicação considera o que há de comum entre elementos diversos e faz desse comum o aspecto com relação ao qual os particulares são subordinadamente assemelhados e que justifica que se os tome como instâncias do conceito. Já no segundo caso, a atribuição afirmativa do conceito esta fundada na consideração da identidade do conteúdo conceitual com o conteúdo da experiência perceptiva considerada, de modo que os particulares a que o conceito demonstrativo vier a ser aplicado, embora numericamente distintos, serão idênticos entre si e idênticos todos ao conteúdo representacional retido, não apenas pelo, mas no conceito demonstrativo, o que é também dizer não só que eles são réplicas, não instâncias, mas que o conteúdo do conceito demonstrativo não é uma nota característica mas uma propriedade sensível, um predicado da intuição como diria Kant. (V. A 88/B 120).

Agora bem, mesmo que se admita que as análises feitas até aqui foram suficientes para que se aceite que a igualdade entre o conteúdo representacional de um dado conceito demonstrativo é iconicamente equivalente ao conteúdo da experiência perceptual com base na qual ele foi formado, ainda não foi clara e suficientemente mostrado como se estabelece a equivalência dele com o conteúdo de novas experiências em que tal conceito, já formado e na posse de um dado sujeito, será por este aplicado a elas. Ora, creio que esse emprego tomará como base para estabelecimento dessa equivalência, mutatis mutandis, o princípio enunciado por Euclides, na abertura do Livro I dos Elementos, quando, ao definir a quarta das denominadas noções comuns, diz: "Coisas que coincidem uma com a outra são iguais entre si." (1952, p. 2)

Gilles Gaston-Granger, a cuja lição sigo neste passo, explica que a noção comum $\mathrm{n}^{\circ} 4$ articula o conceito de igualdade à intuição ao 'permitir a aplicação da igualdade aos objetos da intuição geométrica pela operação de fazer coincidir", o que implica dizer, mais rigorosamente, que há neste caso uma equiparação, muito primitiva, é claro, entre igualdade e congruência. Graças a isso, acrescenta Granger, é estabelecida "uma métrica definida pelo transporte das figuras e pela congruência visualmente realizada (....).”(1968, p. 41) Ora, o que estou a sugerir é que o princípio desta interpretação figurativa da equivalência e a métrica elementar que ela

Manuscrito - Rev. Int. Fil. Campinas, v. 39, n. 3, pp. 199 - 235, jul.-set. 2016. 
estabelece entre grandezas extensivas, podem ser transpostos para as grandezas intensivas, para usar a linguagem de Kant, desde que, no caso das variações cromáticas, substituído o procedimento de determinação da congruência pela superposição das áreas, pelo da superposição parcial, ou pela justaposição contígua dos matizes. É o que creio estar está implicado pela expressão inspeção direta contida na passagem de Mind and World em que McDowell explica o seguinte:

Na presença da amostra original, um sujeito que possui o conceito de um matiz mostra-se capaz, pela inspeção direta da coincidência cromática, de classificar itens, conforme possuam o matiz relevante ou não. (1996, p. 215/2005, p. 172)

É verdade, porém, que não é possível colocar a representação lembrada de um matiz de cor em posição espacial contiguamente justaposta a uma superfície colorida externa e isso me leva diretamente às críticas que podem ser feitas à tese que estou defendendo.

\section{Conceitos demonstrativos e a semântica e pragmática dos padrões de medida}

É preciso, pois, reconhecer que a analise que se acaba de fazer não é isenta de dificuldades e é incontornável tratar de enfrentar o que parecem ser problemas graves nas explicações que acabam de ser dadas sobre o estatuto dos conceitos demonstrativos.

Com efeito, logo depois da conferência em que apresentei a primeira versão deste texto, o Professor Ernesto Perini me fez uma objeção notando que a igualdade entre padrões de cores, como toda igualdade, é uma relação simétrica, o que implica que registrá-la em absoluto basta para constituir qualquer delas em uma amostra no sentido que McDowell emprega o termo quando da introdução do conceito de conceito demonstrativo. ${ }^{21}$ Essa observação, contudo, não é destrutiva, pois se pode tomá-la como simplesmente indicando que o esclarecimento do estatuto conceitos demonstrativos não está concluído.

${ }^{21}$ Em correspondência pessoal.

Manuscrito - Rev. Int. Fil. Campinas, v. 39, n. 3, pp. 199 - 235, jul.-set. 2016. 
Com efeito, para que o isolamento perceptivo de um matiz adquira caráter conceitual não basta vê-lo como igual a um outro. Para isso é preciso transformá-lo em um padrão e isso requer, antes de mais, que se estabeleça uma assimetria entre os termos igualados. Kripke chama atenção para o fato de que. corretamente interpretada, a frase que expressa a definição de "metro" não estabelece a sinonímia entre as expressões "1 metro" e a "extensão do bastão $\mathrm{S}$ no tempo zero", mas "determina a referência da expressão 'um metro." (in Davidson e Harman, 1972, 275). Bem entendido, isso não implica que quem fixou a referência ao escolher uma barra de um certo comprimento o fez com base em uma medida exata, possuída mentalmente de antemão e com a qual coincidiria a barra contingentemente escolhida. Fosse assim, o sentido da frase que expressa a definição de "metro" seria o de explicitar a sinonímia entre duas expressões. $\mathrm{Na}$ verdade, a intenção de estabelecer um padrão métrico não implica, antes exclui, que quem o faça tenha, previamente à instituição do padrão, a medida da unidade de referência. Se fosse assim o instaurador da métrica teria a unidade de medida e, virtualmente, toda a métrica antes de estabelecê-la. Repare-se que a maior dificuldade presente no ponto que acabei de fazer, não é, contudo, esta questão de anterioridade ou posterioridade da unidade de medida ao estabelecimento do padrão, mas antes a questão lógica que está envolvida no estabelecimento de qualquer padrão de medida. Aliás, quem tiver tido a oportunidade e se tenha dado ao trabalho de ler e entender uma vez o primeiro capítulo de $O$ Capital não esquece que a relação entre o que é medido e aquilo que serve e é usado para medi-lo é polarizada e irreversível. 22 Isto quer dizer que a condição lógica para o estabelecimento de um padrão é o rompimento da simetria que constitui a relação de igualdade simples. Isso quer dizer que quando se diz, como no presente contexto, que a cor de um objeto qualquer é a cor do

22 Marx diz: "Por certo, a expressão 20 varas de tecido $=1$ casaco, ou 20 varas de tecido valem um casaco implica também a relação inversa: 1 casaco $=20$ varas de tecido, ou 1 casaco vale 20 varas de tecido. Mas para isso me é ncessário inverter a equação (....). A mesma mercadoria, na mesma expressão do valor, não pode sapresentar-se simultaneamente sob as duas formas. Estas se excluem como dois polos." (1977 [1867] vol. 1, pp. 116 e 117. A passagem citada faz parte do "Suplemento à primeira seção do primeiro capítulo de $O$ Capital, inclusa na primeira edição do livro (1867).

Manuscrito - Rev. Int. Fil. Campinas, v. 39, n. 3, pp. 199 - 235, jul.-set. 2016. 
conceito demonstrativo esse matiz não se está dizendo que esse matižé igual a cor do objeto em questão, mas se está sim dizendo que a cor do objeto coincide com o matiz isolado pela expressão "esse matiz". Parafraseando Marx, pode-se dizer, que, por certo, a expressão 'a cor do objeto $\mathrm{X}=$ este matiz' implica também a relação inversa: 'este matiz $=$ a cor do objeto X', mas para fazer esta segunda afirmação será necessário inverter a equação. Quer dizer, a mesma cor, na mesma expressão de determinação cromática, não pode se apresentar simultaneamente sob as duas formas: como forma relativa e como forma equivalente, para continuar empregando a terminologia de Marx. Estas duas posições se excluem polarizadamente. Além disso, quando trata de evitar o sorites que decorreria se aceitássemos que a identidade "daquele matiz seria determinada sempre que ela fosse indiscernível de uma outra amostra"23, é o próprio McDowell que introduz a mesma assimetria que acabamos de destacar e que, em termos suficientemente claros, ainda que menos claros do que eu desejaria, é apresentado por ele nos seguintes termos:

Não é porque consideramos que algo possui certo matiz que devemos considerá-lo, por isso, uma amostra daquele matiz, capaz de incluir na extensão desse matiz qualquer coisa que seja cromaticamente indiscernível da amostra - é esse passo que nos levaria ao paradoxo. A condição de amostra, determinante da extensão do conceito expresso por 'aquele matiz', deve ser reservada à amostra original (....).(1996, p. 171/2005, p. 2144)

Nesta altura, porém, se coloca uma segunda e mais grave dificuldade: a questão difícil de saber se um padrão pode ser estabelecido sem mediação externa, sem um objeto material colocado fora do universo mental do sujeito, fora da imanência da consciência, para usar uma expressão antiga, pois como também me objetou o Professor Perini:

No caso do metro há um objeto publicamente acessível ao qual diferentes pessoas podem se remeter, de modo que, no caso de um

${ }^{23}$ Nesta passagem McDowell está se posicionando com relação à discussão por Peacocke (V. Peacocke, 1992, p. 83-84) da dificuldade que pode ocorrer em vista de que na experiência perceptiva comum um matiz $X$ pode coincidir com um matiz $Y$ e este coincidir com Z, sem que X coincida com X.

Manuscrito - Rev. Int. Fil. Campinas, v. 39, n. 3, pp. 199 - 235, jul.-set. 2016. 
desencontro entre as duas amostras, um objeto particular exercerá o papel de padrão. Não há nada disso no caso que estamos considerando. Embora a diferença deva ser publicamente acessível, nenhuma das amostras estará aí para funcionar como um padrão em comparações ulteriores; não há nada comparável ao estabelecimento de uma designação ou prática com as requeridas para a introdução de um padrão.(2008)

Este ponto obviamente nos devolve à discussão sobre o estatuto do termo que viabiliza a comparação e ao modo como esta tem lugar, pois como me objetou o Professor Faria, também quando do debate suscitado pela primeira versão deste texto ${ }^{24}$, me caberia responder as seguintes questões: "Como usar uma paleta mental? Não será este um caso em que 'o que quer que me apareça me parecerá correto e será correto para mim?" Indagações que o Professor Faria reforçava escorando-a com várias das anotações de Wittgenstein, dentre as quais a seguinte: "se tudo o que tenho é uma imagem mental, não posso fazer qualquer comparação e 'qualquer coisa que me pareça correta está correta'." Essa dificuldade parece tornar-se ainda mais clara quando se leva na devida conta que o matiz isolado por este matiz não estará armazenado no vácuo em uma sala do Bureau international des poids et mesures (BIPM) em Créteil, mas estará guardado na memória de quem o tiver instituído, a qual, ainda que com a vivacidade que caracteriza a memória de curto prazo, certamente não se compõe de salões iluminados, nem conta com redomas para guardar incontaminada e incorruptivelmente as nuances tomadas como padrões de medida para identificação de cores.

No entanto, a mim parece que essa dificuldade é menos grave do que aparenta e que, como quase sempre, as exigências de certezas absolutas que costumam acompanhar o ceticismo são espantalhos que o prudente e $o$ sensato devem ignorar. Para melhor avaliar a objeção, considere-se, por exemplo, o modo como ao longo do tempo reconhecemos ou desconhecemos as pessoas a quem fomos apresentados e com as quais, para usar a palavra de Russell, somos acquainted. À primeira vista, quando interagimos com frequência com tais pessoas, a memória não parece cumprir qualquer função, pois quando encontro diariamente um colega de trabalho não parece que precise me lembrar dele para cumprimentá-lo. No

${ }^{24}$ Em correspondência pessoal.

Manuscrito - Rev. Int. Fil. Campinas, v. 39, n. 3, pp. 199 - 235, jul.-set. 2016. 
entanto, que essa conclusão seja falsa torna-se manifesto não, por certo, quando se atenta para o que se passa com pessoas de mais idade, pois no caso destas, é evidente que a frequência dos esquecimentos é diretamente causada por deterioração neuronal, mas para as falhas de reconhecimento associadas à mudanças no aspecto dos conhecidos, seja em razão de cirurgias plásticas, seja em decorrência de mudanças de aspecto decorrentes da passagem do tempo, seja em alguns casos por alterações radicais de estilo, como o corte de cabelos, a presença ou ausência de barba, etc. Ora, a lição a tirar de tais casos será a de que, conforme a prescrição de Descartes, deveremos suspender o juízo sobre tais pensamentos não mais lhes dando crédito, como faríamos com as coisas que nos parecem evidentemente falsas?

Uma afirmação do próprio Professor Faria em A preservação da verdade, pode me valer como uma primeira indicação de como sair desse imbróglio. $\mathrm{Na}$ passagem que tenho em vista o Professor Faria diz que "o que é mais distintivo da autoridade da primeira pessoa é a capacidade de exame crítico dos próprios juízos", autoridade que, como ele nota, "supõe a acessibilidade imediata de seu conteúdo". (2006, p. 116) Ao que, porém, convém ainda acrescentar que tal autoridade nem só depende desse acesso imediato aos conteúdos representacionais imanentes à consciência, nem tampouco há de ser compreendida como se fosse a consulta a uma imagem cuja relação com eventuais referentes não fosse objeto senão de palpites, para usar uma expressão de Michael Ayers (2004, p. 245). Como diz Edmund Husserl, a rua lembrada faz exigências, ${ }^{25}$ assim como a rua esquecida cobra seus preços, digo eu. Ou, para ficar com o exemplo que guia esta discussão, como paga o vendedor que esqueceu de anotar o número de referência do matiz escolhido pelo cliente no catálogo da Suvinil. Por certo, tais juízos podem fracassar e é evidente que eles em absoluto assumem que 'qualquer

25 "A fantasia é uma mera modificação da consciência. Ela não põe nada, ela faz 'meramente apresentações'. Se se tratar meramente de fantasia, a objetividade que atribuo a rua lembrada, ao Hohen Weg, terá um estatuto fictício. Já] A rua lembrada tem exigências. As exigências que ela faz estão relacionadas a objetos naturais e, consequentemente, seres humanos com seis cabeças estão excluídos." (2005 [1909], p. 309)

Manuscrito - Rev. Int. Fil. Campinas, v. 39, n. 3, pp. 199 - 235, jul.-set. 2016. 
coisa que me pareça correta será correta', ainda que a retenção da amostra original não seja a percepção dela e o risco de engano seja grande. ${ }^{26}$

Certo, exegeticamente, como também me fez notar o Professor Faria, é o próprio McDowell que adverte sobre os cuidados que é preciso ter quando se fala do cotejo entre o padrão determinado pelo conceito demonstrativo e as cores que venham a ser comparadas com ele. Essa é a razão pela qual este último pondera que é preciso bem interpretar a frase em que a congruência reconhecida nessa comparação é atestada pela declaração "Eu vejo isso com os olbos da mente", pois embora esse

(....) seja um modo legítimo de se fazer a distinção entre possuir o matiz em mente e fazer o pensamento reportar-se a ele por meio de uma especificação (....) pode despertar um pensamento filosoficamente incerto e familiar segundo o qual a evidente correção da frase indica a existência de um mecanismo por meio do qual foi exercida a capacidade classificatória que foi retida. A ideia é que o sujeito atribui o matiz comparando as coisas que ele vê à amostra internamente retida pelo matiz (....) A frase não faz menção a nenhum mecanismo psicológico que estaria operante na produção desses vereditos. (1996, p. 173/2005, p. 216 ) (....) Não haverá nenhuma sustentação adicional, aqui, para a ideia de que exercícios da capacidade recognitiva associada estejam baseados numa comparação com a amostra interna." (1996, p. $174 / 2005$, p. 217 )

\footnotetext{
${ }^{26}$ Uma observação de Goodman vem aqui muito a propósito, pois nela se vê como deve ser reconhecida e como pode ser delimitada a dificuldade de que estamos tratando. Diz Goodman "(....) algumas vezes afirma-se que a identificação de uma qualidade [quale] de uma apresentação a outra está fora de questão porque ela seria extremamente inconfiável e absolutamente intestável. O caráter inconfiável parece evidente em nossa hesitação em decidir se uma apresentação tem a mesma qualidade [quale] que a de uma anterior e em nossa prontidão para mudar de opinião. O caráter intestável parece garantido pelo fato de que a apresentação passada não pode ser revivida atualmente para ser colocada em comparação com a anterior. Mas nenhum tipo de juízo pode ser ao mesmo tempo inconfiável e intestável, porque, afinal, um juízo inconfiável é aquele que é frequentemente denunciado como falso ao ser testado.” (1977, p. 97).
}

Manuscrito - Rev. Int. Fil. Campinas, v. 39, n. 3, pp. 199 - 235, jul.-set. 2016. 
No entanto, essa advertência de McDowell parece-me um regressivo passo na direção do obscurantismo, pois não creio que, a nenhum título, se possa endossar a ideia, que parece sugerida por ele, de que quando um sujeito reconhece um matiz de cor que vê com seus olhos como exatamente congruente com uma amostra retida em sua memória o mecanismo psicológico mediante o qual se perfaz esse reconhecimento não envolva alguma comparação de imagens. Além disso, são as próprias suas ideias de inspeção direta e de comparação direta que perdem sentido se formos obrigados a entendê-las metaforicamente, pois não como há como entender o que seja uma inspeção direta da cor de um objeto e sua comparação direta com um matiz retido mentalmente se não houver neste segundo termo da comparação algo cromático. O que é simplesmente dizer que pensamentos que façam referência direta a matizes de cores ou terão como parte de seu conteúdo o conteúdo cromático dos próprios objetos percebidos, ou estarão determinados pela retenção mnemônica de suas respectivas cores — ou então eles não serão pensamentos sobre matizes de cores.

Bem entendido, se poderia dizer que nós, nós os incréus, somos obrigados a piamente acreditar no milagre da eucaristia, na transformação infinitamente mais frequente do que ocorre pelo mundo quando da consagração das hóstias nas missas - dos resultados de reações eletroquímicas em conteúdos intencionais, de modo que não nos cabe especular como mecanismos neurológicos, subpessoais, transformam relações causais em momentos de nossa vida consciente. Mas não creio que fosse isso o que Wittgenstein tinha em mente quando declarou que se tudo o que tenho é uma imagem mental, não posso fazer qualquer comparação. Seja como for - salvo se se quiser introduzir também no domínio das relações intensionais a crença em algum análogo milagre do reconhecimento direto de matizes sem a evocação mnemônica da imagem do matiz respectivo - não parece haver outro modo de reter um matiz de cor a não ser por meio da retenção da imagem cromática desse matiz. ${ }^{27}$ Sublinhe-se, adicionalmente, que a

\footnotetext{
${ }^{27}$ Goodman tratou de dar uma aparência mais mundana ao reconhecimento do que eu acabo de chamar de 'milagre intencional' atribuindo-o ao instinto: "A comparação de apresentações temporalmente diversas é na verdade imune ao teste da comparação simultânea. Se eu digo que o verde apresentado pela grama agora é o
}

Manuscrito - Rev. Int. Fil. Campinas, v. 39, n. 3, pp. 199 - 235, jul.-set. 2016. 
remissão presumidamente elucidativa de seu ponto feita por McDowell ao referir-se ao exemplo de Wittgentein de que o que tem em mente quem declara que gostaria de saber o que está se passando na cabeça de outrem equivale a simplesmente desejar saber o que ele está pensando é superlativamente infeliz (1996, p. 173/2005, p. 216, nota 8 ), pois se é evidente que não podemos ter acesso direto a imagens que estejam na cabeça de outra pessoa, não é menos evidente que é parte constitutiva do funcionamento da mente de cada ser humano estar capacitado para produzir imagens mentais para si próprio. Como diz Zenon Pylyshyn: "Não pode haver nenhuma questão a respeito de se a experiência da imagística [imagery] existe; não há nem mesmo muito desacordo com relação a seu caráter fenomenal." (2006, p. 288) Aliás, num certo sentido é essa a lição de Wittgenstein quando nos pede que

Imaginemos, de modo semelhante ao do metro-padrão, um modelo das cores conservado em Paris. Assim definimos: 'Sépia' significa a cor sépia padrão que se encontra preservada lá no vácuo. (1958, p. 25)

É verdade que um conceito demonstrativo no sentido de $\mathrm{McD}$ owell não pode estar preservado dessa maneira, mas não parece haver dúvida, de que, se ele é um conceito de cor, sua aplicação tem que ter lugar em termos pelo menos análogos aqueles que estão implicados na ideia wittgensteiniana de que cores são termos empregáveis segundo a lógica dos padrões de medida, no caso como padrões de medida cromática.

Antes de terminar, convém ainda apresentar com mais exatidão tanto as condições de formação dos padrões elementares de medida, quanto a

mesmo que ela apresentava em algum momento passado, não posso verificar essa afirmação revivendo por um momento a apresentação passada. (....) Assim, minha afirmação pode ser encarada como um decreto, mas decretos não são aleatórios. (....) Mas na prática, quando surge um conflito, há duas influências: em primeiro lugar, nós favorecemos o decreto mais 'natural', aquele que for o maximamente sustentado pelo sentimento instintivo de bater no alvo', como quando selecionamos uma cor lembrada; em segundo lugar, favorecemos o decreto que exigir o menor ajuste no corpo de decretos já aceitos." (1977, pp. 98-99). (Negrito acrescentado)

Manuscrito - Rev. Int. Fil. Campinas, v. 39, n. 3, pp. 199 - 235, jul.-set. 2016. 
semântica dos termos que os expressam. Nas análises que dedicou a este ponto em os Imperativos da ilusão, Giannotti sustenta que tal operação exige que a amostra original seja convertida pelo próprio processo de comparação em manifestação sensível de uma identidade pressuposta. Segundo o que dissemos acima, o estabelecimento da amostra não pressupõe nenhuma identidade, senão que institui um padrão para apuração de identificações a serem feitas daí por diante. É verdade, no entanto, que consecução e o êxito do empreendimento de conversão de uma certa tonalidade em amostra envolvem, como vimos, uma espécie de descontextualização interna, de desamarração da tonalidade em questão de seu status natural, a qual, para usar a terminologia de Giannotti, cliva-se ao ter transformada sua identidade sensivel, dada na percep̧cão, na identidade em si do atributo (1983, p. 31). Ou, em linguagem menos especulativa, na nova identidade adquirida pela tonalidade em questão quando de sua transformação em padrão para cotejos e comparações futuras.

Convém ainda assinalar, passando ao que talvez caiba denominar de pragmática dos padrões que essa transformação de objetos do mundo em padrões não ocorre nem descompromissadamente, nem monadicamente, nem intemporalmente. Com efeito, transformar este matiz em um nome de cor só acontece em contextos que estiverem imantados por interesses, nas ocasiões em que nossa atenção lábil e descomprometida com o cromatismo do mundo exigir que os conteúdos, até então não conceptualizados, mas já vistos no curso da experiência, tiverem que ser mobilizados para os propósitos de nossa ação no mundo. De outra parte, a transformação em pauta tampouco poderá ser executada monadicamente, porque, como Giannotti explica no texto referido acima, a fixação de uma cor não somente envolve isolar intencionalmente um matiz, mas requer uma incontornável "comparação efetiva" que implica por o "branco como um não-não-branco" (1983, p. 39). O que equivale a dizer que isolar intensionalmente "este matiz" é uma operação que só pode ser executada relacionalmente, mediante a implicação simultânea de que este matiz não é aquele matiz.

Por fim, cabe ainda insistir em que se a conversão da amostra em conceito, mediante o emprego de demonstrativo complexo, só pode ocorrer na medida em que este último tiver sido transformado no designador de uma amostra padrão, segue-se que a duração temporal exigida por 
McDowell, não pode ser entendida simplesmente como um requisito psicológico da posse de um conceito. Antes, deve-se reconhecê-la como uma condição lógico-transcendental da própria constituição dos conceitos demonstrativos, cuja gênese, acabamos de ver, só pode ter lugar na medida em que for feita a inscrição assimétrica de um certo matiz no espectro das cores e, assim, o isolamento, necessariamente comparativo e mensurador - logo, em alguma medida, temporalmente desdobrado - daquela que, contextualizadamente, se quiser inscrever na paleta com que estruturamos o cromatismo inesgotável da experiência sensível. ${ }^{28}$

Sendo assim, empregada, pois, a corda que McDowell começou a fiar, pode-se dizer que o conteúdo dos conceitos demonstrativos está bem amarrado e que ele, à diferença das estátuas de Dédalo, não nos escapará, o laço que cinge a experiência que lhes dá conteúdo sendo a transformação local do conteúdo desta última em padrão de medida.

Antes de concluir, convém ainda notar, muito en passant, que, dada a complexidade do processo de constituição dos conceitos demonstrativos, não parece que se possa admitir, como parece pretender McDowell, que eles sejam coextensivos a nossa experiência sensível das cores, pois parece muito evidente que o sol já vai bem alto quando passamos a laboriosamente demarcar no domínio vasto e aberto da experiência natural esses padrões de medida. Tratar adequadamente deste ponto, no entanto, não é coisa que se possa fazer no presente contexto.

\footnotetext{
${ }^{28} \mathrm{O}$ que é dizer que não poderemos ter a este matiz como padrão sem colocá-lo no jogo das comparações. Mas colocá-lo no jogo das comparações quer dizer que o isolamento intencional de um matiz - que é a condição para tomá-lo como referência em usos futuros - implica tanto colocá-lo em comparação com os outros matizes com relação aos quais ele é assim ressaltado, quanto mudar-lhe o status de análogo de "o comprimento de $\mathrm{S}$ em $\mathrm{T}_{0}$ ”, para a de análogo do comprimento do metro, para valer-me novamente da análise de Kripke.
}

Manuscrito - Rev. Int. Fil. Campinas, v. 39, n. 3, pp. 199 - 235, jul.-set. 2016. 


\section{Referências}

Almog, J., Perry, J., Wettstein, (eds.) Themes from Kaplan. NewYork Oxford: Oxford Universty Press, 1989.

Ayers, M., Sense Experience, Concepts and Content - Objections to Davidson and McDowell, in Shumacher (ed.), 2004.

Brewer, B. Perception and Reason. Oxford: Oxford University Press, 2003.

Bruner, J., In Search of Pedagogy - Volume I: The Selected Works of Jerome Bruner 1957-1978. New York: Routledge, 2006.

CHUARD, PH., "Demonstrative Concepts without Re-identification". Philosophical Studies, vol. 130, (2006): 153-201.

CODATO, L., "Lições de Giannotti sobre lógica e ontologia" - Entrevista, in Cadernos de Filosofia Alemã - Crítica e Modernidade, 17, (2011): 113-128.

Davidson, D. AND Harman, G. (eds.) Semantics of natural Language, Dordrecht, Holland-Boston: D. Reidel Publishing Company, 1972.

DeLEuZE, G., Différence et repetition. Paris: P.U.F., 1968.

DERRIDA, J., Gramatologia, trad. De Miriam Schnaiderman e Renato Janine Ribeiro, São Paulo: Perspectiva - EDUSP, 1973.

Dognin P.-D, Les «sentiers escaprés de Karl Marx - Le chapitre I du «Capital» traduit et commenté dans trois rédactions successives. Paris: Les Édition du Cerf, 1977.

EUCLIDES, Os treze livros dos Elementos. Great Books of the Western World, II, New York: Encyclopedia Britannica, Inc., 1952.

Evans, G. Varieties of Reference. Oxford: Oxford University Press, 1992

FARIA, P., "A preservação da verdade", O Que nos Faz Pensar (PUCRJ), v. 20, p. 101-126, 2006.

, Correspondência pessoal. 2007.

FOrD, A., HORNSBY, J. AND STOUTLAND, FR. Essays on Anscombe's Intention. Cambridge, Mass.: Harvard University Press, 2011.

- Action and Generality. (in Ford e alii, 2011).

GiannotTi, J. A., Os imperativos da ilusão, em Trabalho e Reflexão, São Paulo: Brasiliense, 1983.

Goodman, N., The Structure of Appearance. Dordrecht, HoillandBoston:D. Reidel Publishing Company, 1977.

Granger G.-G., Filosofia do Estilo, São Paulo: Editora Perspectiva, 1968. Husserl, Texto $\mathrm{n}^{\circ} 7$ in Husserl ([1909],2005).

Manuscrito - Rev. Int. Fil. Campinas, v. 39, n. 3, pp. 199 - 235, jul.-set. 2016. 
EDmund Husserl, Phantasy, Image Consciousness, and Memory (1898-1925), Dordrecht: Springer, 2005. (Esse volume contém a tradução para o inglês, de John B. Brough, do volume XXIII da Husserliana.

KANT, I. Lectures on Logic, New York: Cambridge University Press, 1992.

Lectures on Metaphysics. New York: Cambridge University Press, 1997.

Metaphysik Mrongovius, (in Kant, 1997).

The Vienna Logic (in Kant, 1992).

KaPlan, D. Demonstratives. in Almog, Perry e Wettstein, 1989.

Kelly, S. D., "Demonstrative Concepts and Experience". The Philosophical Review, Vol. 110, No. 3 (Jul., 2001).

KRIPKE, S. Naming and Necessity (in Davidson, D. and Harman, G. (eds.), 1972.

Lepore, E. E Ludwig, K. "The Semantics and Pragmatics of Complexes Demonstratives". Mind, vol. 109, (abril de 2000), pp. 199-233.

Margolis, E. E Lawrence, S. (eds.) Concepts - Core Readings, Cambridge, Mass.:The MIT Press, 2000.

MCDOweLL, J. Mind and World, Cambridge Mass.: Harvard University Press, 1996. Tradução brasileira de João V. G. Cuter, intitulada Mente e Mundo, São Paulo: Ideias \& Letras, 2005.

Platão, Menon, 97c-98a. Tradução de Jorge Paleikat, Porto Alegre: Editora Globo, 1962.

PANACCIO, CL. Les mots, les concepts et les choses. Montréal e Paris: Belarmin e Vrin, , 1991.

Peacocke, C., Précis of A Study of Concepts, (in Margolis, E. e Lawrence, S. eds. 2000).

PERINI, E.. Correspondência pessoal, 2008.

Perry, John, The Peoblem of the Essential Indexical and Other Essays, Stanford, California. CSLI Publications, 2000.

Quine W. van O., Word and Object. Cambridge, Mass.:The MIT Press, 1999 (1960).

Schumacher, R., (ed.) Perception and Reality from Descartes to the Present. Paderborn: Mentis, 2004.

WitTgenstein, Philosophical Investigations. $3^{\text {th }}$ Edition, translated by G. E. Anscombe, New York: Macmillan Publishing Co., Inc, 1958.

Manuscrito - Rev. Int. Fil. Campinas, v. 39, n. 3, pp. 199 - 235, jul.-set. 2016. 
PYLYSHYN, Z. Seeing and Visualizing - It's Not What You Think, Cambridge, Mass.: The MIT Press, 2006. 